\title{
Management Accounting Information System and the Financial Performance of Consumer Goods Firms in Nigeria
}

\author{
Benjamin Ezugwu Onodi, Oti Ibiam, and Jane Chinyere Akujor
}

\section{ABSTRACT}

This study examined the effect of management accounting information system on the performance of listed consumer goods firms in Nigeria. The objectives of the study were to ascertain the effect of sales management system, management accounting reporting system and budgetary management system on the profitability of listed consumer goods firms in Nigeria. A survey research design was adopted and appropriately used for this study and 100 copies of questionnaire were administered to employees from the selected consumer goods companies. Data collected were analyzed with the aid of percentages and tables while statistical tools used for testing the hypotheses were simple regression analysis and ANOVA. The findings of this study revealed that; sales management system, management accounting system and budgetary management system affect profitability of listed consumer goods firms in Nigeria positively. The study concludes that accounting information system is critical to the production of quality accounting, sales and budget reports (information) on a timely basis and the communication of that information to the decision makers. The researchers recommend that organizations should strengthen their salesforce for effective revenue generation, ensure that management accounting reporting is timely and accurate for effective decision making, and budgetary control should be put in place for monitoring of activities of the business.

Keywords: Accounting information system, Management information system, Sales management system, Budgeting management system \&Consumer goods firms' performance.
Published Online: February 3, 2021

ISSN: $2507-1076$

DOI: $10.24018 /$ ejbmr.2021.6.1.684

Benjamin Ezugwu Onodi *

Department of Accounting, Michael Okpara College of Agriculture, Umudike, Abia State, Nigeria.

(e-mail: benonodi@yahoo.com)

Oti Ibiam

Department of Accounting, Michael Okpara College of Agriculture, Umudike, Abia State, Nigeria.

Jane Chinyere Akujor

Department of Financial Management Technology, School of Management Technology, Federal University of Technology, Owerri, Imo State, Nigeria.

*Corresponding Author

\section{INTRODUCTION}

Accounting is the language for business communication as observed by Reference [19], while Reference [18] posits that accounting is the science and art of collecting, classifying, summarizing and communicating data of financial nature required to make economic decisions. Management accounting information system in collaboration with Information and Technology (IT), were designed to help in the management and control of activities related to firms' economic and financial transactions. Accounting information is a part of company's information system that facilitates decision making within the firm and should be fitted to firms' environment, requirements of task, and structure. Accountants, consultants, business analysts, managers, chief financial officers (CFOs), auditors and regulatory agencies consider an accounting information as a structure that a firm uses to collect, store, manage, process, retrieve and report its financial data.

In developed economies management accounting information system provides suitable framework for financial managerial decisions of firms that is not lacking in quality. Society will be better off if researches can improve decision making through improved information, since the world has become a global village as a result of rapid worldwide technological and socio-political changes. It is important to note that every industry and sectors' success, and in some cases survival, depend on the ability of organizations to compete globally. In recent time, organizations of all types, including business, government, education, health care, military, and research and development, have changed their operations and management approaches. These organizations have all felt the pressure to operate more effectively because of the prevailing circumstances, such as cutbacks in funding, escalating costs, competition for limited resources, and a demand for higher-quality outcomes.

Business managers in the $21^{\text {st }}$ century must react to the competitive threats not only from local source but also from regional, national and international source. They must seek to explore all opportunities that are available in the immediate, national and global environments because deregulation has increased competitive pressure for organizations to survive, grow and prosper. Managers must employ a lot of the resources at their disposal as efficiently as possible so as to accomplish the objectives and goals of the enterprise in a competitive environment. Information in form of reports prepared by managers and many business professionals are made possible by Management Information System (MIS). For example, sales managers may use their network computer and web browser to get 
instantaneous display about the sales results of their daily sales analysis report to evaluate sales made by each sales personnel. Management Information System is a formalized procedure to provide management at all levels and in all functions with appropriate information to enable them to make timely and effective decisions for planning, directing, evaluating, and controlling the activities for which they are responsible.

Management Information System (MIS) has a great influence on the market share portion, revenue generation, sales volume achieved, recruitment of best qualified candidates, the goodwill of the enterprise and the customers' perception about the organization and its output. It supplies decision makers with facts, supports and enhances the overall decision making process. The effective delivery of an enterprise's products and services are supported by the management information system. Management information systems should be comprehensive, accessible, flexible and useable at the appropriate levels of the organization's activities.

\section{Statement OF THE PROBLEM}

Traditional accounting information aimed at the calculation of profit has been of limited value for control in recent time. In this era of knowledge economy, Managers need all kinds of non accounting information about the external environment such as social, economic, political, and technical development. A major task also facing management in almost every field of endeavour is to plan carefully so that the quantity and quality of information obtained will be adequate to meet its needs. Information Technology (IT) and Financial accounting system are important functional elements or parts of the total management information system structure. The prevailing economic conditions and competition create pressures about costs of information and most firms continue to increase spending on information system and their budgets continue to rise. Generally, information system is developed using information technology to aid an individual in performing his job and firms focus on developing information system in order to support decision system, communication, and knowledge management. Accounting information system provides a base to a firm, to deal with its vendors, customers and employees, but uncertainties surround the prediction of how growing need for accounting information system will change the productivity and performance of the firm. Since most firms have not incorporated the use of better accounting information systems in their day to day transactions, the researchers wish to examine the effect of management accounting information system on the performance of listed consumer goods firms in Nigeria.

\section{RESEARCH OBJECTIVES}

The main objective of this study is to determine the effect of management accounting information system on the performance of selected listed consumer goods firms in Nigeria.

The specific objectives include the following:
1. To examine the effect of sales management system on the profitability of selected listed consumer goods firms in Nigeria.

2. To determine the effect of management reporting system on the profitability of selected listed consumer goods firms in Nigeria.

3. To investigate the effect of budgeting system on the profitability of selected listed consumer goods firms in Nigeria.

\section{RESEARCH QUESTIONS}

In line with the above objectives, the research questions are thus:

1. To what extent does sales management system affect the profitability of selected listed consumer goods firms in Nigeria?

2. To what extent does management reporting system affect the profitability of selected listed consumer goods firms in Nigeria?

3. How does budgeting system affect the profitability of selected listed consumer goods firms in Nigeria?

\section{HYPOTHESES}

The hypotheses are stated in null form thus:

1. $\mathrm{HO}_{1}$ : Sales management system does not have any significant effect on the profitability of selected listed consumer goods firms in Nigeria.

2. $\mathrm{HO}_{2}$ : Management reporting system does not have any significant effect on profitability of selected listed consumer goods firms in Nigeria.

3. $\mathrm{HO}_{3}$ : Budgeting system does not have any significant effect on the profitability of selected listed consumer goods firms in Nigeria.

\section{REVIEW OF RELATED LITERATURE}

\section{A. Concept of Management Information System}

Management Information System (MIS) is the development and uses of information system that help businesses achieve their goals and objective. Management accounting information system provides communication needed to carry out the managerial functions and for linking the organizations with its external environment. The focus in Management Information System coupled with improved processing has led to the reduction in bottlenecks attached to management process. A system is a group of components that interact to achieve some purpose. Reference [16] posits that an Information System (IS) is a group of components (computer hardware, software, data, procedures and people), that interact to produce information. These five components are present in every information system, for example, when you use a computer to write a report, you are using hardware (the computer, storage disk, keyboard, and monitor), software (word, or other word-processing program), data (the words, sentences, and paragraphs), procedures (the methods you use to start the program to enter, save and back up), and people (you).It is important to 
note that Information is knowledge derived from data, whereas data is defined as recorded fact or figures.

Accounting information as part of the management information System involves the effective combination of resources within the firm in order to provide actionable information for firm's performance. Quality accounting information that will enhance the performance of organizations has been one of great concern as lack of concentration on this key management technique has caused a lot of havoc to so many organizations. Inadequate accounting information has drastically reduced the confidence of the public in the financial statements of many companies. There is a need to ensure that reliability is placed on the accounting information provided by management in order to increase public confidence and organizations are expected to put effective management accounting information system in place.In terms of effectiveness, accounting information makes use of accounting techniques and controls within the information technology framework to track all financial transactions of a firm so as to make available internal and external report on the activities of the business (Reference [12]). Therefore, accounting information should satisfy user's requirement, that is, it should provide users with relevant information on firm's performance.

\section{B. Value Relevance and Efficient of Accounting Information}

Value relevance is measured as the statistical relationship between financial statement information and capital market values or returns of firms, while efficient accounting information is one that provides quality information that would be appropriate, timely, current, and accessible to all users. Reference [6], agrees that value relevance research investigates the relationship between a security price dependent factor and a set of independent accounting factors. Informational perspective measures the effect of accounting report to individual users without much emphasis on the precise structure of the relationship between accounting information and firm value as stated in Reference [7]. The key commonality in the definitions is that an accounting data is deemed value relevant if it has a significant relationship with security market value. The information perspective of value relevance is used for this study to determine the value relevance of accounting data of listed consumer goods firms in Nigeria. The prompt recording and proper classification of transactions where necessary information is generated on timely basis are necessary for the above conditions to be achieved. It is important to note that for the information so generated to be made available to the right people, proper and working controls must be put in place. Efficiency of the accounting information from the perspective of systems controls was observed by Reference [20]. They define systems controls as subsystems within information systems that are within the accounting, and interrelated with accounting. In their study the identified feedback systems and feed-forward systems, hence control monitors the system to ensure efficiency and effectiveness of operations. They advocated that flow of effective communication should occur in all directions, flowing down, across and up the firm, throughout all components and the entire structure. Monitoring is accomplished through routine activities, separate evaluation of activities or a combination of both.

\section{Sales Management System}

Reference [3]defines sales management as; "the planning, direction, and control of personnel, selling activities of a business unit including recruiting, selecting, training, assigning, rating, supervising, paying, motivating, as all these tasks apply to the personnel sales-force". The benefits of selling activities include the following:

1. Creates and stimulate demand;

2. Offers assistance to customers;

3. Adopts suitable means and techniques of profitable selling of goods and services for business firms; and

4. Keeps the firms abreast or ahead of competition.

Sales management incorporates some principles of management into its control system known as elements of sales management. Such elements include planning, coordination, controlling and motivation. It is important to note that the objectives of sales management of corporate firm are geared toward achieving sufficient sales volume, providing sufficient profit, and experiencing continuing growth. The practical application of sales techniques and the management of a firm's sales operations are normally referred to as Sales management and control system. It is an important business function as sales through the sale of products and services and resulting profit drive most commercial corporate firms. The sales management and control system monitors and measures each staff members' ability to either support sales or do the actual selling to customers. An effective sales management strategy includes setting goals, providing sales support and training, creating or updating the sales strategy, and monitoring results.

\section{Budgetary Control Systems}

Budgeting is a systematic and formalized approach for accomplishing the planning, coordination and control responsibilities of management [19] cited in Reference [10]. She posits that budgeting is a coordination of these plans through management control and responsibilities as to achieve quantified plan which is formalized. A budget is a financial plan for a defined period, and it involves planned sales volumes and revenues, resource quantities, costs and expenses, assets, liabilities and cash flows. Budgetary control is a system of controlling costs which includes the preparation of budgets, co-ordinating the departments and establishing responsibilities, comparing actual performance with the budgeted and acting upon results to achieve maximum profitability. Budgetary control is part of corporate planning system. Corporate planning is interwoven with budgeting and it serves as a system for coordinating the setting of objectives, preparing budgets and plans, mapping out strategies, preparing policy and procedures and monitoring of performance and results. In order to perform the control function effectively, managers need information accurately and timely to monitor progress toward their goals and turn plans into reality. Unless right information is given, managers in the organization cannot stay on track or anticipate potential problems or decide corrective actions. Key features of budgetary control systems as observed by Reference [10] are: 
1. Actionable objectives setting;

2. Identification of executive responsibility and assigning of roles;

3. Mapping out strategy to achieve the objectives;

4. Determination of variance by comparing actual result against the plan;

5. Measures for corrective actions;

6. Feedback and revising plans in the light of changes.

The purpose of budgeting is to provide forecast of income and expenditure, serve as tool for decision making and to monitor business performance.

\section{E. Firms' Performance Management}

Performance management is a systematic process for improving organizational performance by developing the performance indices of individuals and teams. It is a means of getting better results by understanding and managing performance within an agreed framework of planned goals, standard and competency requirements (Reference [5]). Performance management contributes to the achievement of culture change and it is integrated with other key Human Resources (HR) activities, especially human capital management, talent management, learning and development and reward management. Performance management is a process for establishing shared understanding about what is to be achieved and how it is to be achieved, and an approach to managing and developing people that improves individual, team and organizational performance. Specifically, performance management is concerned with:

1. Matching individual objectives to organizational objectives;

2. Defining target to be achieved in terms of role responsibilities and accountabilities;

3. Creating enabling environment and opportunities for individuals to identify their own goals and develop their skills and competencies;

4. Provision of incentive for advancement and motivating people by providing them with recognition and the opportunity to use and develop their skills and abilities.

Performance management general objective is to develop and improve the performance of individuals and teams and that of the organization. It is an instrument that can be used to achieve culture change, develop the capacity of people to meet and exceed expectations and to achieve their full potential to the benefit of themselves and the organization at large.

\section{THEORETICAL FRAMEWORK}

\section{A. Systems Theory}

The systems theory offers solutions to handle complex situations of the input and output flows. It uses theory of communication which helps to evolve a system design capable of handling data inputs, process, and outputs with the least possible noise or distortion in transmitting the information from a source to destination. System theory treats an organization as a system and a system can be either closed or open but most researches treat an organization as open system. Systems theory is a blend of principles, theories and practices of management, information and system giving rise to a single product called Management Information System. Reference [9]; posit that an open system interacts with its environment by way of input, throughput and output. An organization receives resources such as equipment, natural resources, and the work of employees, referred to inputs. The inputs are transformed, called throughput and then yield products or services called output. Feedback loops provide information to the organization by connecting outputs to the inputs. A negative feedback loop indicates a problem that should be corrected. For example, the failure of product design indicated by the need to recall the product. A positive feedback loop can identify outputs that have worked well. For example, successful marketing campaign that yields high sales. Thus, feedback loops are a means of confirming success or signalling that correction to the system need to be made.

\section{EMPIRICAL REVIEW}

In the study conducted by Reference [16], in Jodhpur hotels in India on the impact of Accounting Information System in planning, controlling and decision -making processes. Descriptive analytic method was employed and questionnaire was the research instrument used to collect data from various hotel accountants. After the statistical analysis of the questionnaire, findings revealed that most hotels in Jodhpur didn't embrace accounting information system in planning, control and decision making processes. The study therefore concluded that there is no relationship between accounting information system and planning, controlling and decision making in four and five star Jodhpur hotels in India.

Reference [13] conducted a study on accounting information and stock volatility in the Nigeria capital market. The study made use of secondary data from Nigeria Stock Exchange Fact Book for the period under review using GARCH model (a statistical model that can be used to analyze a number of different types of financial data). The result from the model revealed that accounting information explains and account for stock volatility in the Nigerian stock market, specifically, information on carrying values, earning per share, and dividend per share are found to be related to stock volatility.

Reference [17]in their work on accounting information system and organizational effectiveness in selected construction companies in Ibadan Nigeria used descriptive and inferential statistics tools to analyze the data with the aid of statistical package for social sciences (SPSS). ANOVA was used in testing the hypotheses and the results revealed that accounting information system has effect on organizational effectiveness.

A study by Reference [1] on management accounting practices (MAPs) in the food and drinks industry in the U.K. was geared towards the understanding of the level of MAP's sophistication and the factors that affect implementation of MAPs in consumer goods industry. The research instrument used was a survey questionnaire sent to 650 executives of the consumer goods firms. Two hundred and Forty-five (245) usable completed copies of questionnaire were received and analyzed. Respondents' responses was analyzed using a Likert scale (1 indicating 
never and 5 indicating very often). The study found that as companies moved into a more uncertain environment, the sophistication level of management accounting practices increased. Likewise, as their power relative to customers' diminished, companies moved up the stages of evolution. The study concludes that the management accounting systems employed in many food and drinks companies were not particularly sophisticated and there was little evidence of management accounting directly connected with 'value creation'.

Reference [8] carried out a study on management accounting information and public sector organization. The study adopted cross sectional survey research design and targeted a population of 18 ministries under the national government. Data were collected using primary source and a questionnaire based on five-point Likert scale, oral interviews were also utilized. Qualitative data obtained were examined using both content analysis and SPSS for quantitative data. The research finding revealed that management accounting information supports decision making in an organization.

Reference [2] conducted a survey in New Zealand manufacturing firms and the techniques adopted in their business. While many previous studies have focused on particular techniques such as ABC or target costing, Adler et al. provided a questionnaire that included a vast array of management accounting information techniques to provide a fuller set of response options. Their finding revealed that management accounting information is necessary for organizational productivity.

Reference [14] conducted a study on the value relevance of accounting information and stock prices of listed banks at Karachi stock exchange in which the pooled regression technique was used on nineteen private banks. Their findings show that earning per share is more value relevant than carrying values, while accounting data explained a high proportion of the stock price. The study concludes that accounting information system influences the economic decision of users by helping them evaluate past, present and future events.

Reference [12] which investigated the relationship between accounting information and organizational effectiveness; showed that there was strong relationship between accounting information and organizational effectiveness, which means access to accounting information, will lead to organizational effectiveness.
Several recent studies on value of accounting information for equity valuation, share price and earnings prediction have queried current financial reporting model in the developed world. Reference [4] in their study of management accounting practices in India analyzed the responses furnished by 53 CFOs in Indian corporations on their management accounting system. The survey questionnaire also aimed to verify any significant difference between management accounting information and company growth revealed a positive relationship between the two variables.

Although, numerous studies have been carried out on the effect of accounting information on the financial performance of listed consumer firms, but none of the studies dealt with sales management and budgetary control systems, hence this work has filled that gap.

\section{Methodology}

This work adopted the survey research design. The study focused on consumer goods firms in Nigeria using PZ Cusson and Nigeria Breweries. Sample size of 100 was purposively selected from the members of staff of the companies. Data obtained were analyzed using the SPSS and statistical tools such as frequency distribution, percentage, regression analysis were also used for analysis.

\section{MOdel SPECIFICATION}

The model for this study is stated as follows:

$$
\begin{aligned}
& \mathrm{OP}=\mathrm{f}(\mathrm{SMS}, \mathrm{MRS}, \mathrm{BMS}) \\
& \mathrm{OP}=\beta_{0}+\beta_{1} \mathrm{SMS}+\beta_{2} \mathrm{MRS}+\beta_{3} \mathrm{BMS}+\mathrm{e}
\end{aligned}
$$

Where

OP = Organizational Performance (Profitability).

SMS = Sales Management System .

MRS = Management Reporting System.

BMS = Budgeting Management System.

$\beta_{0}=$ Intercept term.

$\beta_{1}, \beta_{2} \& \beta_{3}=$ Slope co-efficient.

$\mathrm{e}=$ error term.

\begin{tabular}{|c|c|c|c|c|c|c|}
\hline $\begin{array}{l}\mathrm{S} / \\
\mathrm{N}\end{array}$ & $\begin{array}{l}\text { Questionnaire items on independent variables (Sales, reporting \& budgeting } \\
\text { systems) }\end{array}$ & SA & A & $\mathrm{U}$ & $\mathrm{D}$ & SD \\
\hline 1 & $\begin{array}{l}\text { Sales management system involves planning, directing and control of } \\
\text { personnel and selling activities of sales-force. }\end{array}$ & $40(50 \%)$ & $30(37.5 \%)$ & $2(2.5 \%)$ & $4(5 \%)$ & $4(5 \%)$ \\
\hline 2 & $\begin{array}{l}\text { Efficient management reporting system is the one that provides quality } \\
\text { information that would be appropriate, timely, current and accessible to all } \\
\text { users. }\end{array}$ & $30(37.5 \%)$ & $36(45 \%)$ & $0(0 \%)$ & $10(12.5 \%)$ & $4(5 \%)$ \\
\hline 3 & $\begin{array}{l}\text { One of the key features of budgeting system is comparing actual result against } \\
\text { the plan and taking corrective actions on the deviation from the plan. }\end{array}$ & $30(37.5 \%)$ & $30(37.5 \%)$ & $12(15 \%)$ & $4(5 \%)$ & $4(5 \%)$ \\
\hline 4 & $\begin{array}{l}\text { Reliable information enhances the management decision making of a } \\
\text { business. }\end{array}$ & $34(42.5 \%)$ & $30(37.5 \%)$ & $4(5 \%)$ & $8(10 \%)$ & $4(5 \%)$ \\
\hline 5 & Proper disclosures of financial information promote the growth of a business. & $26(32.5 \%)$ & $30(37.5 \%)$ & $0(0 \%)$ & $14(17.5 \%)$ & $10(12.5 \%)$ \\
\hline 6 & $\begin{array}{l}\text { Adequate timeliness of report of financial information shows business } \\
\text { organizations' competence. }\end{array}$ & $40(50 \%)$ & $24(30 \%)$ & $2(2.5 \%)$ & $10(12.5 \%)$ & $4(5 \%)$ \\
\hline 7 & Accounting systems practices are integral culture in your organization. & $44(55 \%)$ & $15(18.5 \%)$ & $5(6.25 \%)$ & $6(7.5 \%)$ & $10(12.5 \%)$ \\
\hline 8 & Adequate measures must be kept for organization to plan ahead. & $35(43.75 \%)$ & $20(25 \%)$ & $6(7.5 \%)$ & $11(13.75 \%)$ & $8(10 \%)$ \\
\hline 9 & $\begin{array}{l}\text { Proper forecasting measures must be put in place by management in order to } \\
\text { determine suitable mark-up on cost. }\end{array}$ & $40(50 \%)$ & $20(25 \%)$ & $0(0 \%)$ & $15(18.5 \%)$ & $5(6.25 \%)$ \\
\hline
\end{tabular}

TABLE I: PERCENTAGE ANALYSIS OF RESPONDENTS' RESPONSES TO QUESTIONNAIRE 
TABLE I (CONTINUATION): PERCENTAGE ANALYSIS OF RESPONDENTS' RESPONSES TO QUESTIONNAIRE

\begin{tabular}{|c|c|c|c|c|c|c|}
\hline & Questionnaire items on dependent variable (Profitability) & SA & A & $\mathrm{U}$ & $\mathrm{D}$ & SD \\
\hline 10 & Proper and adequate follow up of customers must be emphasized for growth. & $48(60 \%)$ & $22(27.5 \%)$ & $0(0 \%)$ & $7(8.25 \%)$ & $3(3.75 \%)$ \\
\hline 11 & $\begin{array}{l}\text { Cost reduction must be given prompt and timely attention in order to make } \\
\text { the business profitable. }\end{array}$ & $46(57.5 \%)$ & $20(25 \%)$ & $2(2.5 \%)$ & $10(12.5 \%)$ & $2(2.5 \%)$ \\
\hline 12 & $\begin{array}{l}\text { Reliable information enhances the management of a business in decision } \\
\text { regarding marketing strategy. }\end{array}$ & $20(25 \%)$ & $43(53.75 \%)$ & $3(3.75 \%)$ & $9(11.25 \%)$ & $5(6.25 \%)$ \\
\hline 13 & $\begin{array}{l}\text { There is no budget for training and retraining of sales-force in your } \\
\text { organization. }\end{array}$ & $5(6.25 \%)$ & $8(10 \%)$ & $2(2.5 \%)$ & $42(52.5 \%)$ & $23(28.75 \%)$ \\
\hline 14 & $\begin{array}{l}\text { Proper accountability is useful for estimating the earning potential of the } \\
\text { firm. }\end{array}$ & $50(62.5 \%)$ & $15(18.75 \%)$ & $0(0 \%)$ & $9(11.25 \%)$ & $6(7.5)$ \\
\hline 15 & $\begin{array}{l}\text { Organizations' integrity about financial information enhances customers' } \\
\text { confidence. }\end{array}$ & $42(52.5 \%)$ & $20(25 \%)$ & $4(5 \%)$ & $8(10 \%)$ & $6(7.5 \%)$ \\
\hline 16 & $\begin{array}{l}\text { Good customer relation is not only effective but efficient in your } \\
\text { organization. }\end{array}$ & $40(50 \%)$ & $34((42.5 \%)$ & $0(0 \%)$ & $4(5 \%)$ & $2(2.5 \%)$ \\
\hline 17 & $\begin{array}{l}\text { Information and communication technology does not enhance management } \\
\text { decision making in product innovation. }\end{array}$ & $10(12.5 \%)$ & $8(10 \%)$ & $2(2.5 \%)$ & $40(50 \%)$ & $20(25 \%)$ \\
\hline 18 & Customer benefit and value added strategies are necessary in profit planning. & $44(55 \%)$ & $15(18.5 \%)$ & $5(6.25 \%)$ & $6(7.5 \%)$ & $10(12.5 \%)$ \\
\hline
\end{tabular}

Source: Researchers' computation, 2019.

TABLE II: DISTRIBUTION OF QUESTIONNAIRE AND RESPONSE RATE

\begin{tabular}{ccc}
\hline Copies of & Respondents & Percentage (\%) \\
questionnaire & 80 & 80 \\
Number returned & 20 & 20 \\
Number not returned & 100 & 100 \\
Total & &
\end{tabular}

From Table II, out of 100 copies of questionnaire distributed to the respondents, 80 representing $80 \%$ were correctly filled and returned while 20 representing $20 \%$ were not valid. This shows that a good number of questionnaires were attended to and therefore can assist in generating information necessary for the study.

Question one: Sales management system involves planning, directing and control of personnel and selling activities of sales-force.

TABLE III: FREQUENCY DISTRIBUTION OF RESPONDENT'S RESPONSE TO

\begin{tabular}{ccc} 
& QUESTION ONE ABOVE & \\
\hline Option & Respondents & Percentage $(\%)$ \\
\hline Strongly agree & 40 & 50 \\
Agree & 30 & 37.5 \\
Disagree & 4 & 5 \\
Strongly disagree & 4 & 5 \\
Undecided & 2 & 2.5 \\
Total & 80 & 100 \\
\hline Source: Field survey, 2018 & &
\end{tabular}

Source: Field survey, 2018.

Table III shows that 50 percent of the total respondents strongly agree, and 37.5 percent agree that sales management system affect organizational performance, 5 percent disagree, and 5 percent strongly disagree while 2.5 percent were undecided.

Question two: Efficient management reporting system is the one that provides quality information that would be appropriate, timely, current and accessible to all users.

TABLE IV: FREQUENCY DISTRIBUTION OF RESPONDENT'S RESPONSES TO QUESTION TWO ABOVE

\begin{tabular}{ccc} 
& QUESTION TwO ABOVE & \\
\hline Option & Respondents & Percentage (\%) \\
\hline Strongly agree & 30 & 37.5 \\
Agree & 36 & 45 \\
Disagree & 10 & 12.5 \\
Strongly disagree & 4 & 5 \\
Undecided & - & - \\
Total & 80 & 100 \\
\hline
\end{tabular}

Source: Field survey, 2018.

Table IV revealed that 37.5 percent of the respondent strongly agree that Management reporting system affect organizational performance, 45 percent agree, 12.5 percent disagree, while 5 percent strongly disagree.

Question three: One of the key features of budgeting system is comparing actual result against the plan and taking corrective actions.

Table V shows that 37.5 percent of the respondents strongly agree and 37.5 percent agree that budgeting system affect organizational performance, 12.5 percent disagree, 12.5 percent strongly disagree, while 15 percent were undecided.

TABLE V: FREQUENCY DISTRIBUTION OF RESPONDENT'S RESPONSES TO

\begin{tabular}{ccc} 
& QUESTION THREE ABOVE \\
\hline Option & Respondents & Percentage $(\%)$ \\
\hline Strongly agree & 30 & 37.5 \\
Agree & 30 & 37.5 \\
Disagree & 4 & 12.5 \\
Strongly disagree & 4 & 12.5 \\
Undecided & 12 & 15 \\
Total & 80 & 100 \\
\hline
\end{tabular}

Source: Field survey, 2018.

Question four: Reliable information enhances the management decision making of a business.

TABLE VI: FREQUENCY DISTRIBUTION OF RESPONDENT'S RESPONSES TO

\begin{tabular}{ccc} 
& QUESTION FOUR ABOVE & \\
\hline Option & Respondents & Percentage $(\%)$ \\
\hline Strongly agree & 34 & 42.5 \\
Agree & 30 & 37.5 \\
Disagree & 8 & 10 \\
Strongly disagree & 4 & 5 \\
Undecided & 4 & 5 \\
Total & 80 & 100 \\
\hline
\end{tabular}

Source: Field survey, 2018.

Table VI shows that 42.5 percent of the total respondents strongly agree that Reliable information enhances the management of a business, 37.5 percent agree, 10 percent disagree 5 percent strongly disagree, and 5 percent were undecided.

Question five: Proper disclosures of financial information promote the growth of a business.

TABLE VII: FREQUENCY DISTRIBUTION OF RESPONDENT'S RESPONSE TO

\begin{tabular}{ccc} 
& QUESTION FIVE ABOVE \\
\hline Option & Respondents & Percentage $(\%)$ \\
\hline Strongly agree & 26 & 32.5 \\
Agree & 30 & 37.5 \\
Disagree & 14 & 17.5 \\
Strongly disagree & 10 & 12.5 \\
Undecided & - & - \\
Total & 80 & 100 \\
\hline
\end{tabular}

Source: Field survey, 2018. 
Table VII revealed that 32.5 percent of the respondents strongly agree, and 37.5 percent agree that proper disclosures of financial information promote the growth of a business, 17.5 percent disagree, while 12.5 percent strongly disagree.

\begin{tabular}{ccccc}
\multicolumn{5}{c}{ TABLEVIII: MODEL SUMMARY } \\
\hline Model & $\mathrm{R}$ & R Square & $\begin{array}{c}\text { Adjusted R } \\
\text { Square }\end{array}$ & $\begin{array}{c}\text { Std. Error of the } \\
\text { Estimate }\end{array}$ \\
\hline 1 & $.831^{\mathrm{a}}$ & .766 & .763 & .30605 \\
\hline a. Predictors: (Constant), Sales management system.
\end{tabular}

\begin{tabular}{cccccc}
\multicolumn{5}{c}{ TABLE IX: ANOVA $^{\mathrm{a}}$} \\
\hline Model & $\begin{array}{c}\text { Sum of } \\
\text { Squares }\end{array}$ & df & Mean Square & F & Sig. \\
Regression & 40.510 & 1 & 40.510 & 45.690 & $.000^{\mathrm{b}}$ \\
1 Residual & 6.265 & 38 & .165 & & \\
Total & 46.775 & 39 & & & \\
\hline
\end{tabular}

a. Dependent Variable: Decision making (Sales Management).

b. Predictors: (Constant), Profitability.

TABLE X: COEFFICIENTS ${ }^{\mathrm{a}}$

\begin{tabular}{|c|c|c|c|c|c|}
\hline \multirow[t]{2}{*}{ Model } & \multicolumn{2}{|c|}{$\begin{array}{c}\text { Unstandardized } \\
\text { Coefficients }\end{array}$} & \multirow{2}{*}{$\begin{array}{c}\begin{array}{c}\text { Standardized } \\
\text { Coefficients }\end{array} \\
\text { Beta } \\
\end{array}$} & \multirow[t]{2}{*}{$\mathrm{T}$} & \multirow[t]{2}{*}{ Sig } \\
\hline & $\mathrm{B}$ & Std. Error & & & \\
\hline (Constant) & .461 & .296 & & $\begin{array}{c}1.45 \\
7\end{array}$ & .128 \\
\hline $\begin{array}{c}\text { SALES } \\
\text { MANAGEM } \\
\text { ENT } \\
\text { SYSTEM }\end{array}$ & 1.061 & .068 & .931 & $\begin{array}{c}14.6 \\
75\end{array}$ & .000 \\
\hline
\end{tabular}

a. Dependent Variable: Profitability.

b. Predictors: (Constant), Profitability.

Based on the model summary, the $\mathrm{R}^{2}$ of 0.766 shows that about $76.6 \%$ of the variation in profitability is explained by sales management system. The remaining $24.6 \%$ is as a result of other variables not captured in the model. Based on the ANOVA table, the F-calculated 45.690 is greater than the F-tabulated of 1.96 (from statistical table) this shows that there is a relationship between sales management system and profitability. From the regression table the tstatistics of 1.557 means that there is a positive relationship between sales management system and profitability. This means that $1.557 \%$ increase in sales management system, will lead to $14.675 \%$ increase in profitability.

\section{A. Test of Hypothesis one}

Decision: Since the P-value of 0.00 is less than 0.05 , we reject the null hypothesis and accept the alternative hypothesis and conclude that sales management system has a significant effect on the profitability of selected listed firms in Nigerian Stock Exchange.

TABLE XI: MODEL SUMMARY ${ }^{\mathrm{b}}$

\begin{tabular}{cccccc}
\multicolumn{7}{c}{ TABLE XI: MODEL SUMMARY } \\
\hline Model & R & R Square & $\begin{array}{c}\text { Adjusted R } \\
\text { Square }\end{array}$ & $\begin{array}{c}\text { Std. Error of } \\
\text { the Estimate }\end{array}$ & $\begin{array}{c}\text { Durbin- } \\
\text { Watson }\end{array}$ \\
\hline 1 & $.801^{\mathrm{a}}$ & .712 & .707 & .42636 & .813 \\
\hline
\end{tabular}

a. Predictors: (Constant), Management reporting.

b. Dependent Variable: Profitability.

TABLE XII: ANOVA $^{\mathrm{a}}$

\begin{tabular}{|c|c|c|c|c|c|c|}
\hline & Model & $\begin{array}{c}\text { Sum of } \\
\text { Squares }\end{array}$ & Df & Mean Square & $\mathrm{F}$ & Sig. \\
\hline \multirow{3}{*}{1} & Regression & 29.867 & 1 & 29.867 & \multirow[t]{3}{*}{$\begin{array}{c}18.30 \\
2\end{array}$} & \multirow[t]{3}{*}{$.000^{\mathrm{b}}$} \\
\hline & Residual & 6.908 & 38 & \multirow[t]{2}{*}{.182} & & \\
\hline & Total & 36.775 & 39 & & & \\
\hline
\end{tabular}

a. Dependent Variable: Profitability.

b. Predictors: (Constant), Management Reporting.

\begin{tabular}{|c|c|c|c|c|c|c|}
\hline \multicolumn{7}{|c|}{ XIII: COEFFICIENTS ${ }^{\mathrm{a}}$} \\
\hline & \multirow[t]{2}{*}{ Model } & \multicolumn{2}{|c|}{$\begin{array}{l}\text { Unstandardized } \\
\text { Coefficients }\end{array}$} & \multirow{2}{*}{$\begin{array}{c}\text { Standardized } \\
\text { Coefficients } \\
\text { Beta }\end{array}$} & \multirow[t]{2}{*}{$\mathrm{T}$} & \multirow[t]{2}{*}{ Sig. } \\
\hline & & $\mathrm{B}$ & Std. Error & & & \\
\hline \multirow[b]{2}{*}{1} & (Constant) & .432 & .347 & & 1.246 & .220 \\
\hline & $\begin{array}{l}\text { Management } \\
\text { Reporting }\end{array}$ & 1.050 & .082 & .901 & 12.818 & .000 \\
\hline
\end{tabular}

Based on to the model summary, the $\mathrm{R}^{2}$ of 0.712 shows that about $71.2 \%$ of the variation in profitability is explained by management accounting reporting. The remaining $28.8 \%$ is as a result of other variables not captured in the model. Based on the ANOVA table, the Fcalculated 18.302 is greater than the F-tabulated of 1.96 (from statistical table) this shows that there is a relationship between management reporting and organizational profitability. From the regression table the t-statistics of 1.246 means that there is a positive relationship between management reporting and organizational profitability. This means that $1.246 \%$ increase in management reporting will lead to $12.818 \%$ increase in profitability.

\section{B. Test of Hypothesis Two}

Decision: Since the P-value of 0.015 is less than 0.05 , we reject the null hypothesis and accept the alternative hypothesis and conclude that Management reporting system has a significant effect on the profitability of selected listed firms in Nigerian Stock Exchange.

TABLE XIV: MODEL SUMMARY ${ }^{\mathrm{b}}$

\begin{tabular}{cccccc}
\hline Model & $\mathrm{R}$ & R Square & $\begin{array}{c}\text { Adjusted R } \\
\text { Square }\end{array}$ & $\begin{array}{c}\text { Std. Error of the } \\
\text { Estimate }\end{array}$ & $\begin{array}{c}\text { Durbin- } \\
\text { Watson }\end{array}$ \\
\hline 1 & $.845^{\mathrm{a}}$ & .793 & .790 & .46171 & .596 \\
\hline
\end{tabular}

a. Predictors: (Constant), Budgeting system.

b. Dependent Variable: Profitability.

TABLE XV: ANOVA $^{\mathrm{a}}$

\begin{tabular}{ccccccc}
\hline \multirow{2}{*}{ Model } & $\begin{array}{c}\text { Sum of } \\
\text { Squares }\end{array}$ & df & $\begin{array}{c}\text { Mean } \\
\text { Square }\end{array}$ & \multirow{2}{*}{ F } & \multirow{2}{*}{ Sig. } \\
\hline \multirow{2}{*}{1} & Regression & 67.674 & 1 & 67.674 & 17.458 & $.000^{\mathrm{b}}$ \\
& Residual & 8.101 & 38 & .213 & & \\
& Total & 75.775 & 39 & & & \\
\hline
\end{tabular}

a. Dependent Variable: Profitability.

b. Predictors: (Constant), Budgeting system.

\begin{tabular}{|c|c|c|c|c|c|c|}
\hline \multicolumn{7}{|c|}{ XVI: COEFFICIENTS ${ }^{\mathrm{a}}$} \\
\hline & \multirow[t]{2}{*}{ Model } & \multicolumn{2}{|c|}{$\begin{array}{l}\text { Unstandardized } \\
\text { Coefficients }\end{array}$} & \multirow{2}{*}{$\begin{array}{c}\text { Standardized } \\
\text { Coefficients } \\
\text { Beta }\end{array}$} & \multirow[t]{2}{*}{$\mathrm{t}$} & \multirow[t]{2}{*}{ Sig. } \\
\hline & & $\mathrm{B}$ & Std. Error & & & \\
\hline \multirow[b]{2}{*}{1} & (Constant) & .035 & .212 & & .167 & .868 \\
\hline & $\begin{array}{c}\text { Budgeting } \\
\text { System }\end{array}$ & .938 & .053 & .945 & 17.817 & .000 \\
\hline
\end{tabular}

a. Dependent Variable: Profitability.

Based on to the model summary, the $\mathrm{R}^{2}$ of 0.793 shows that about $79.3 \%$ of the variation in profitability is explained by budgeting system. The remaining $20.7 \%$ is as a result of other variables not captured in the model.

Based on the ANOVA table, the F-calculated 317.458 is greater than the F-tabulated of 1.96 (from statistical table) this shows that there is a relationship between budgeting system and organizational profitability. From the regression table the t-statistics of 0.167 means that there is a positive relationship between budgeting system and organizational profitability. This means that $0.167 \%$ increase in budgeting system will lead to $17.817 \%$ increase in profitability. 


\section{Test of Hypothesis Three}

Decision: Since the P-value of 0.015 is less than 0.05 , we reject the null hypothesis and accept the alternative hypothesis and conclude that budgeting system has significant effect on the profitability of selected listed firms in Nigerian Stock Exchange.

\section{DISCUSSION ON FINDINGS}

The findings in hypothesis one revealed that sales management system has a significant effect on the profitability of selected listed firms in Nigerian Stock Exchange. These findings support the view of Hunton (2014), which states that essence of management accounting information affects organizational profitability.

The findings in hypothesis two revealed that management reporting system has a significant effect on the profitability of selected listed firms in Nigerian Stock Exchange. These findings support the view of Adler et al (2015), which states that management information system affects organizational growth. The findings in hypothesis three revealed that Budgeting system has a significant effect on the profitability of selected listed firms in Nigerian Stock Exchange. This was revealed p-value of .000 significant less than .05 level of significance.

\section{SUMMARY OF FINDINGS, CONCLUSION AND RECOMMENDATIONS}

\section{A. Summary of Findings}

Based on the objectives of this study, data analysis, and discussion of findings and fieldwork information, the following findings were summarized:

1. Sales management system has a significant effect on the profitability of selected listed firms in Nigerian Stock Exchange. This was revealed by the t-statistics of 1.557 which that $1.557 \%$ increase in sales management system, will lead to $14.675 \%$ increase in profitability.

2. Management reporting has a significant effect on the profitability of selected listed firms in Nigerian Stock Exchange. The t-statistics of 1.246 means that $1.246 \%$ increase in management reporting will lead to $12.818 \%$ increase in profitability.

3. Budgeting system has a significant effect on the profitability of selected listed firms in Nigerian Stock Exchange. The t-statistics of 0.167 means that $0.167 \%$ increase in budgeting system will lead to $17.817 \%$ increase in profitability.

\section{B. Recommendations}

Based on the findings of this study, the following recommendations were made:

1. Business decision today guarantees the continuous existence of the business and the effectiveness of the decision made by the management is as a result of the information given. Therefore, management should maintain an effective and efficient sales-force that will be equipped in skills and knowledge.

2. Information is useful when it is relevant and timely, therefore management accountants are required to provide information on time so as to hasten up in making vital decision because undue delay in decision making will definitely undermine the firms' goal of profit maximization.

3. Since the world is advancing day by day and technology as well, it is advisable that the management of the company should give adequate attention on monitoring and control of operations. Training programmes, appraisal and evaluation of performance are put in place in order to acquaint managers with the new technologies in vogue and keep pace with new knowledge.

Management information system should be seen as an important tool for decision making process in an organization and more encouragement should be given to staff in the performance of their duties. This will enhance efficiency and effectiveness of the accounting information in the manufacturing firms.

\section{REFERENCES}

[1] Abdul-kadar, K. and Luther, M. (2016). Management Accounting Practices in the Food and Drink Industries in the UK.International Journal of Accounting Information Systems, 4 (11).

[2] Adler, R., Everatt, A. M and Waldron, E. (2015). Advance management accounting techniques in decision making utilizations.University of South Australia publication. Accounting forum Business, ISSN:0015-9982

[3] America Marketing Association (1965).Marketing and economic development: Chicago, Peter D. Bennett (ed.).

[4] Anand, P., Edward, J., \& Robert, T. (2014).The association between the use of sophisticated capital accounting and budgeting practices and corporate performance.The Engineering Economist, 46, (4), 300311.

[5] Armstrong, M.(2009). Handbook of Performance Management: An Evidence-based Guide, London; Institute of Personnel and Development

[6] Beaver, W. H., \&Demski,J. (2011). The nature of financial accounting objectives: A summary and synthesis. Journal of Accounting Research3(3), 170-182.

[7] Bernard, V. (2014). The feltham-ohlson framework: Implications for empiricists. Contemporary Accounting Research 4(3), 733-747.

[8] Biwott, M.D. (2015). Management Accounting Information: Its impact on company's growth. Journal of Information systems, Spring 8-9.

[9] Chikere, C. C. \&Nwoka, J. (2015). The systems theory of management in modern day Organizations: A study of Aldgate Congress Resosrt Ltd. Port-Harcourt.International Journal of Sceintific and Research Publications 5 (9), ISSN 2250-3153

[10] Eyisi, A. S. (2003). Cost accounting:Theories \&practice.Enugu, published by His Favour's point.

[11] Grande, E.U., Estebanez,R.P. \&Colomina,C.M. (2012). The impact of accounting information systems (AIS) on performance measures: Empirical evidence in Spanish SMEs. The International Journal of Digital Accounting Research, 11(3): 25 - 43

[12] Hunton, J. E. (2014). Blending information and communication technology with accounting research, Accounting Horizons,16(1), 55-67.

[13] Ikhatua, O.J. (2017). Internal Controls: The case of Nyanya Bus Service Corporation, A Masters project submitted to Department of Accountancy, University of Nigeria.

[14] Khurram,E. and Aisha, M.(2014). Budgetary participation and managerial performance: The impact of information and environmental volatility. Account Review; 67 (5), 11-26.

[15] Kroenke, D. M. (2011).Using MIS, third edition, New Jersey: Prentice hall.

[16] Omar, A. \& Ali, H. (2018).The role of accounting data in performance evaluation.Empiricalresearch in accounting supplement.Journal of Accounting Research, 10, 156-182.

[17] Onaolapo, M and Odetayo H, (2016). Assessing the impact of human resource accounting information on managerial decisions: A field experiment. Personnel Review, 17 (3), 29 - 35

[18] Onodi, B. E. (2019). Modern Business and Financial Accounting: Principles \& Practice for beginners and undergraduates. Ibadan: Jumak Digital and Publishing. 
[19] Osisioma, B. C. (1990). Studies in Accountancy: Text and readings, Enugu, Acenapsublishers.

[20] Robinson L. A., Davis, J. R. \& Alderman C. W. (2012). Accounting information systems: A cycle approach (2nd edition). New York: Harper and Row, publishers. 